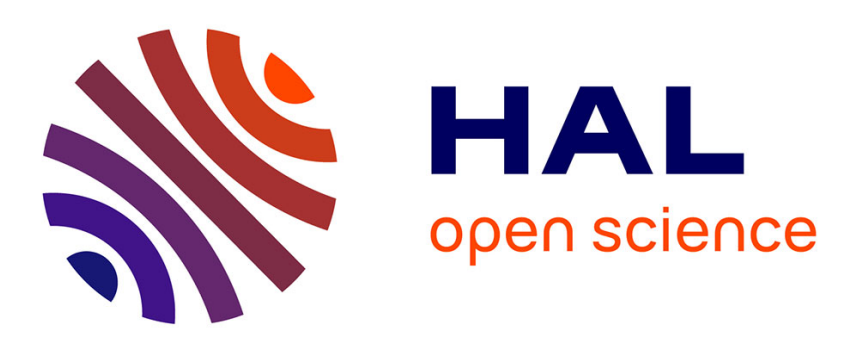

\title{
Comprehensive experimental investigation of mechanically induced 1,4-diazines synthesis in solid state
}

Paulo F. M. Oliveira, Naoki Haruta, Alain Chamayou, Brigitte Guidetti, Michel Baltas, Kazuyoshi Tanaka, Tohru Sato, Michel Baron

\section{- To cite this version:}

Paulo F. M. Oliveira, Naoki Haruta, Alain Chamayou, Brigitte Guidetti, Michel Baltas, et al.. Comprehensive experimental investigation of mechanically induced 1,4-diazines synthesis in solid state. Tetrahedron, 2017, 73 (16), p.2305-2310. 10.1016/j.tet.2017.03.014 . hal-01619243

\section{HAL Id: hal-01619243 \\ https://hal.science/hal-01619243}

Submitted on 8 Nov 2018

HAL is a multi-disciplinary open access archive for the deposit and dissemination of scientific research documents, whether they are published or not. The documents may come from teaching and research institutions in France or abroad, or from public or private research centers.
L'archive ouverte pluridisciplinaire HAL, est destinée au dépôt et à la diffusion de documents scientifiques de niveau recherche, publiés ou non, émanant des établissements d'enseignement et de recherche français ou étrangers, des laboratoires publics ou privés. 


\title{
Comprehensive experimental investigation of mechanically induced 1,4-diazines synthesis in solid state
}

\author{
Paulo F.M. Oliveira ${ }^{\text {a, b, *, Naoki Haruta }}{ }^{\mathrm{c}, 1}$, Alain Chamayou ${ }^{\mathrm{a}}$, Brigitte Guidetti ${ }^{\mathrm{b}}$, \\ Michel Baltas ${ }^{\text {b, }{ }^{* *}}$, Kazuyoshi Tanaka ${ }^{c}$, Tohru Sato ${ }^{\text {c, d }}$, Michel Baron ${ }^{\text {a, }{ }^{* * *}}$ \\ a Centre RAPSODEE, CNRS UMR 5302, Université de Toulouse, Mines-Albi, Campus Jarlard, 81013 Albi, France \\ b Laboratoire SPCMIB, CNRS UMR 5068, Université de Toulouse, UPS, 118 Route de Narbonne, 31062 Toulouse, France \\ ${ }^{\mathrm{c}}$ Department of Molecular Engineering, Graduate School of Engineering, Kyoto University, Nishikyo-ku, Kyoto 615-8510, Japan \\ ${ }^{\mathrm{d}}$ Unit of Elements Strategy Initiative for Catalysts \& Batteries, Kyoto University, Nishikyo-ku, Kyoto 615-8510, Japan
}

\section{A B S T R A C T}

Compared mechanosynthesis of two condensed 1,4-diazines were investigated in ball milling conditions from o-phenylenediamine. ${ }^{13} \mathrm{C}$ CP-MAS NMR revealed a hemiaminal intermediate for dibenzo[a,c] phenazine synthesis accumulated under mechanical action, as confirmed by calorimetry. Such intermediate, which is not detected in the case of 2,3-diphenylquinoxaline synthesis, provides experimental evidence of a concerted reaction between highly reactive mechanically-excited diamine and 9,10phenanthrenequinone.

Keywords:

Mechanochemistry

Ball milling

Reaction intermediates

Reaction mechanism

Diazines

\section{Introduction}

1,4-Diazines such as phenazines and quinoxalines are an important class of nitrogen heterocyclic compounds with interesting applications in chemistry and materials science. ${ }^{1,2}$ These scaffolds are also commonly found in biologically active structures and drug pharmacophores. ${ }^{3-6}$ Phenazines and quinoxalines derivatives have been classically synthesized in solution media, but more recently, alternative ways such as mechanochemistry have been used to prepare diazines. ${ }^{7-9}$

Mechanochemistry has been highlighted as an efficient route to prepare different classes of chemicals. ${ }^{10-14}$ Organic mechanosyntheses often proceed rapidly, in solvent-free conditions with high yields $^{10,15,16}$ and selectivity ${ }^{17,18}$ and can originate unexpected

\footnotetext{
* Corresponding author. Present address: Université de Lille, UMET, Unité Matériaux et Transformations, CNRS UMR 8207, F-59 000 Lille, France.

** Corresponding author.

*** Corresponding author

E-mail addresses: pmarques@mines-albi.fr (P.F.M. Oliveira), baltas@chimie.upstlse.fr (M. Baltas), baron@mines-albi.fr (M. Baron).

1 Present address: Hybrid Materials Unit, Institute of Innovative Research, Tokyo Institute of Technology, S2-6, 4259 Nagatsuta, Midori-ku, Yokohama 226-8503, Japan.
}

reaction pathways. ${ }^{19}$ Neat or liquid-assisted grinding of powders showed also to afford either known or novel products that cannot be prepared otherwise. ${ }^{20-24}$ Although the macromechanisms of such transformations have been extensively described, ${ }^{11 b, 14,25-29}$ the consequences of mechanical stresses on atomic and electronic levels remain to be further investigated. The mechanical stresses can deform the molecules in the crystal lattice and certain bonds, inducing orbital deformation, 30,31 "inverse Jahn-Teller effect" and HOMO-LUMO gap closure, ${ }^{31-33}$ minimizing the activation barriers for reactions. The solid properties are also responsible to promote or hamper product formation. ${ }^{16,34}$

The reaction between o-phenylenediamine (1) and 9,10phenanthrenequinone (2a) under ball milling conditions yielding dibenzo[a,c]phenazine (3a) (Scheme 1) was previously investigated by the group. ${ }^{8}$ The experimental results indicated the reaction continuation after the milling and a possible push-pull stepwise mechanism was proposed for this post-grinding period. ${ }^{8 \mathrm{~b}}$ Vibronic coupling density and Density Functional Theory (DFT) calculations were used to elucidate the mechanisms and energetic barriers of this same reaction. ${ }^{35}$ A concerted mechanism for addition of diamine $\mathbf{1}$ to the dione $\mathbf{2 a}$ was considered to be possible under continuous mechanical excitation while this level of energy is not reasonably achieved by thermal activation. ${ }^{35}$ More recently, the ball milling reaction between $\mathbf{1}$ and benzil (2b) to yield 2,3- 


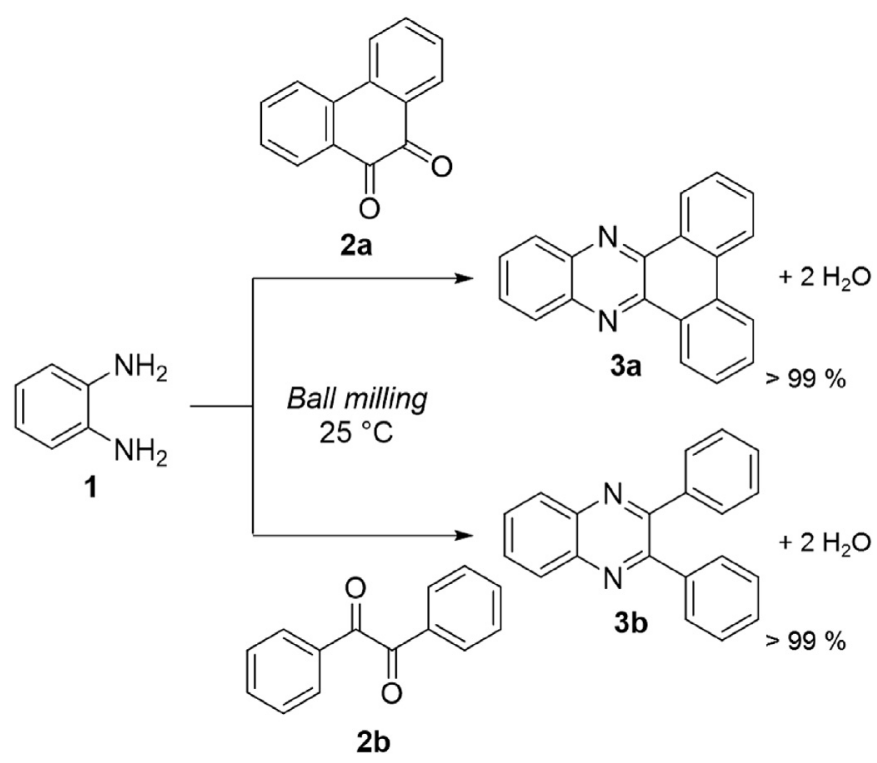

Scheme 1. Mechanosynthesis of condensed 1,4-diazines (3a and $\mathbf{3 b}$ ) from the reaction between solids 1,2-diamine $\mathbf{1}$ and 1,2-diones $\mathbf{2 a}$ and $\mathbf{2 b}$.

diphenylquinoxaline (3b) (Scheme 1) was studied. ${ }^{9}$ It was observed a possible reduction of the activation energy caused by the mechanical energy at lower temperatures, whereas a liquid phase occurred when milling at higher temperature, concomitant with an activation energy similar to the one of a thermal reaction. ${ }^{9}$

Based on the previous results of the group on mechanosynthesis of condensed 1,4-diazines $\mathbf{3} \mathbf{a}$ and $\mathbf{3} \mathbf{b}^{8,9,35}$ and in continuation of our efforts to get a comprehensive mechanistic insight, we wish to report here our recent investigations of these reactions concerning the conditions favoring a concerted or a stepwise mechanism under mechanical milling. In that aim, the kinetic behavior at room temperature was determined while calorimetry and ${ }^{13} \mathrm{C}$ CP-MAS NMR techniques were also used.

\section{Results and discussion}

The mechanosyntheses of 1,4-diazines were carried out by comilling solid o-phenylenediamine (1), and 1,2-diones; 9,10phenanthrenequinone (2a) and benzil (2b) to yield, respectively, dibenzo[a,c]phenazine (3a) and 2,3-diphenylquinoxaline (3b)

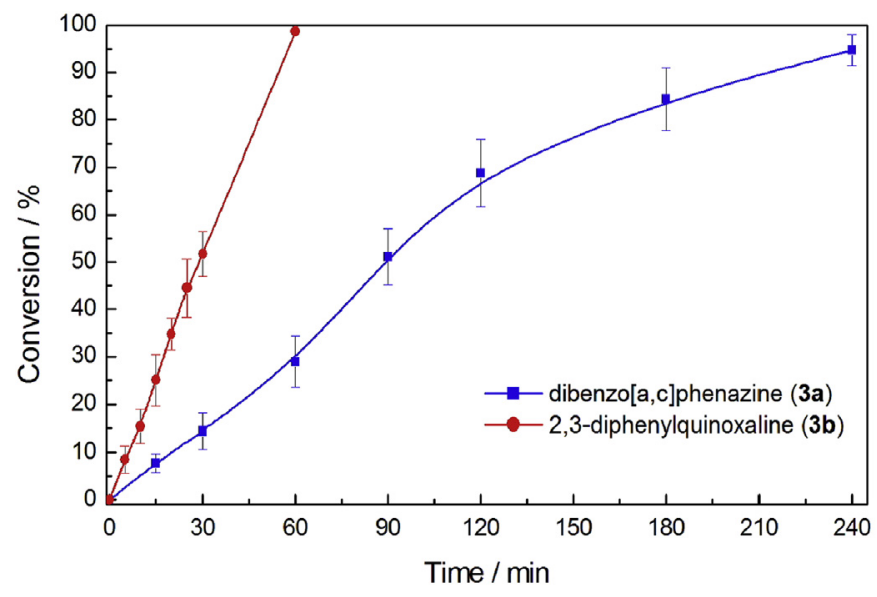

Fig. 1. Kinetics of transformation for condensed 1,4-diazines mechanosynthesis.
(Scheme 1).

The differences on the overall kinetics of transformation for $\mathbf{3 a}$ and 3b syntheses, followed by HPLC (Fig. 1), suggested different reaction mechanisms. While for $\mathbf{3 b}$ the reaction reaches completion in $60 \mathrm{~min}$, a fourfold increase of continuous milling is necessary to produce 3a quantitatively. This was attributed to the higher electrophilic character and chemical reactivity of $\mathrm{C}=\mathrm{O}$ group of $\mathbf{2 b}$ compared to that of $\mathbf{2} \mathbf{a}^{36}$ and to solid state constrains, ${ }^{16,34}$ such as $\mathrm{H}$-bonding, reactive site exposure, and flexibility of $\mathbf{2} \mathbf{b}$ compared to the flat rigid molecule $\mathbf{2 a}$. The formation of compound $\mathbf{3 b}$ follows an apparent zero-order reaction type ${ }^{9}$ (Fig. 1, red line), whereas that of 3a approaches a sigmoidal. This can include not only chemical reactions, but also physicochemical aspects such as diffusional limitations, nuclei formation and growth behavior. This latter could represent the overall kinetics of 3a synthesis, thus suggesting that once several nuclei are created during the first $60 \mathrm{~min}$, the first crystallites of product formed act as templates increasing the reaction rate. The effect of seeding was previously reported for other mechanically induced reactions in ball mill. 37,38

${ }^{13} \mathrm{C}$ CP-MAS NMR spectra were recorded for both reactions in the course of the milling period. For $3 a,{ }^{13} \mathrm{C} C P$-MAS NMR spectra evidenced a $\mathrm{C}-\mathrm{OH}$ signal at $\delta=81.0 \mathrm{ppm}$ (Fig. 2a), representing a signature of a hemiaminal intermediate generated upon consumption of $\mathbf{1}$ and $\mathbf{2 a}$ and evolving progressively towards the aromatic product 3a. It is noteworthy to point out that this intermediate was not detected during the $\mathbf{3 b}$ synthesis (Fig. $2 \mathbf{b}$ ).

It is also interesting to point the splitting of the $C=0$ signal observed for compound 2a in Fig. $2 \mathrm{a}$ ( $\delta=180.0$ and $175.5 \mathrm{ppm}$ ), that can be attributed to environmental effects of the solid state. ${ }^{39,40}$ The crystalline 2a has two crystallographic distinct molecules in the asymmetric unit cell, whatever the polymorphic form. ${ }^{41,42}$ This gives two chemical shifts in the solid-state NMR spectra for a chemically equivalent entity. ${ }^{39,40}$ In the case of $\mathbf{2 b}$, half the molecule composes the asymmetric unit with the symmetric axis across the $\mathrm{C}-\mathrm{C}$ center bond. ${ }^{43,44}$ As consequence, one signal in ${ }^{13} \mathrm{C}$ CP-MAS NMR is assigned to the $\mathrm{C}=\mathrm{O}(\delta=195.0 \mathrm{ppm}){ }^{45,46}$

In Fig. $2 \mathrm{a}$, the $\mathrm{C}=\mathrm{O}$ signals of $\mathbf{2 a}$ decrease similarly as the duration of the milling increases. The molecules of $\mathbf{2 a}$ must be detached from the crystal lattice by reacting with $\mathbf{1}$ to yield the $\mathrm{C}-\mathrm{OH}$ hemiaminal intermediate. Contrary to the starting material, the intermediate is not able to crystallize easily and orderly and presents a single ${ }^{13} \mathrm{C}$ NMR shift. All the signals from the diamine $\mathbf{1}$ also decrease clearly in the course of the reaction, and after $240 \mathrm{~min}$, the ${ }^{13} \mathrm{C}$ CP-MAS NMR is identical to pure 3a obtained by recrystallization from ethanol (Fig. 2, green spectrum).

Under continuous milling, no intermediate bearing both a $\mathrm{C}=\mathrm{O}$ and $\mathrm{a} C=\mathrm{N}$ group, indicating a stepwise mechanism, was detected. Actually, the ${ }^{13} \mathrm{C}$ resonance of the $\mathrm{C}=\mathrm{N}$ of this intermediate is expected around $\delta=160 \mathrm{ppm}^{47-50}$ On the other hand, DFT calculations and vibronic coupling density theory previously demonstrated the theoretical possibility of a concerted mechanism for 3a mechanosynthesis. ${ }^{35}$ This scenario is corroborated by NMR (Fig. 2a), with both carbonyl groups transformed into hemiaminal by direct concerted addition, giving the intermediate $\mathbf{A B}$ (Fig. 3a) under application of mechanical energy. The unusual stability of $\mathbf{A B}$ can be attributed to the fact that the water elimination in this rigid molecule is disfavored in the absence of solvent.

Such concerted addition needs both amino groups located fleetingly on the same sides of the aromatic nucleus. ${ }^{35}$ However, the amino groups of $\mathbf{1}$ are located on opposite sides of the aromatic plane, ${ }^{51}$ giving the crystal structure stability by hydrogen bonds. But, the huge amount of energy supplied to the powder by mechanical action, ${ }^{52}$ disintegrates the crystal and provides the shortlived activated form of $\mathbf{1},{ }^{35} \mathbf{1}^{*}$ (Fig. $3 \mathbf{b}$ ), reacting with $\mathbf{2 a}$ according to a concerted mechanism, generating the cis-bis-hemiaminal 
(a)

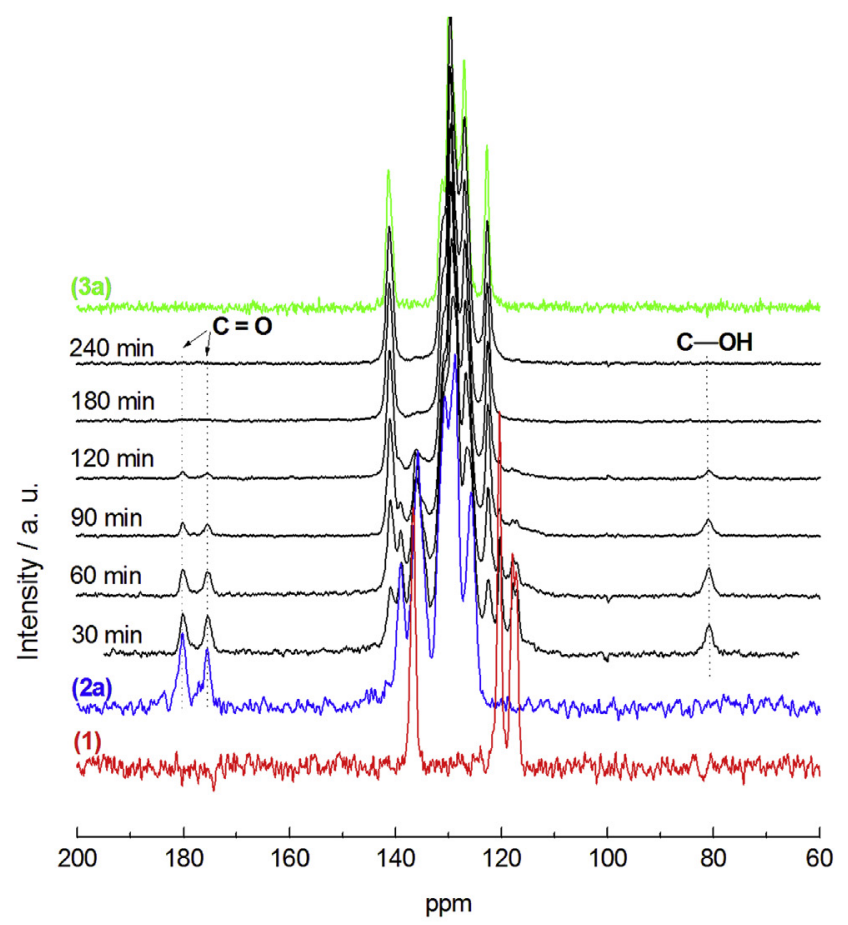

(b)

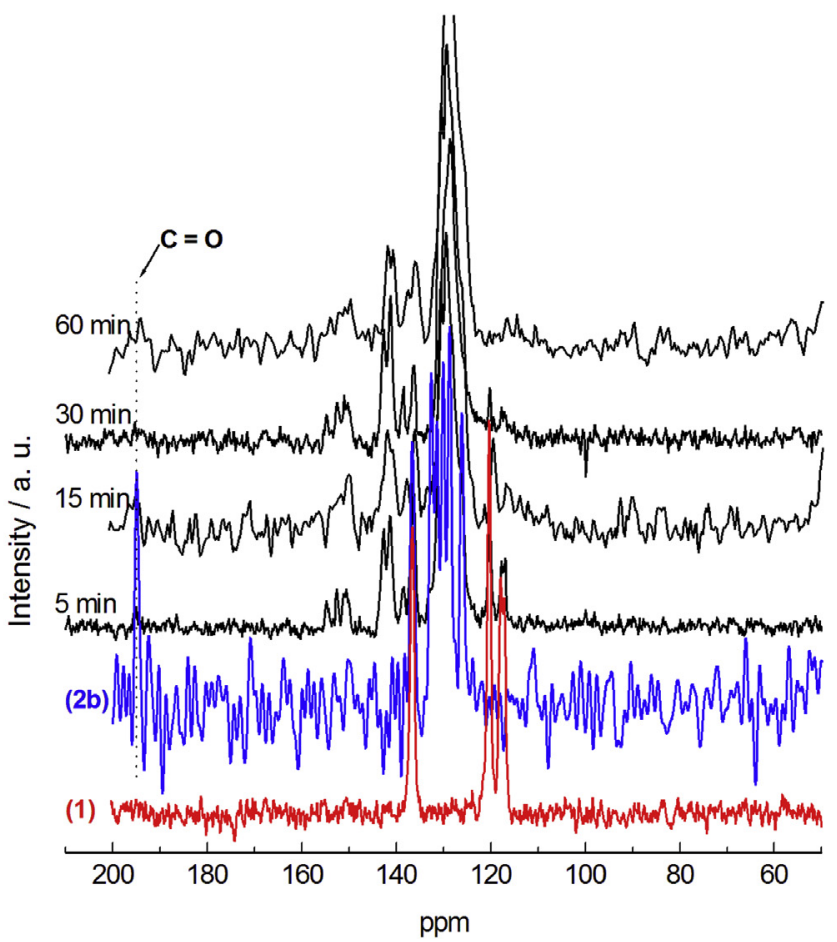

Fig. 2. ${ }^{13} \mathrm{C}$ CP-MAS NMR spectra of mechanosynthesis at different milling times: (a) 3a and (b) $\mathbf{3 b}$ synthesis.

a)

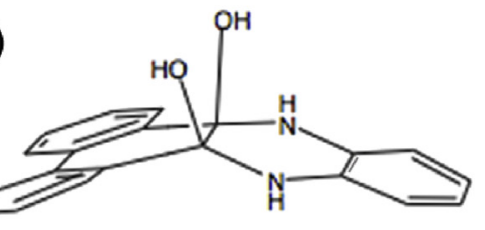

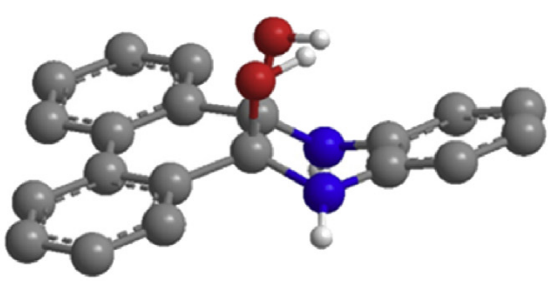

b)
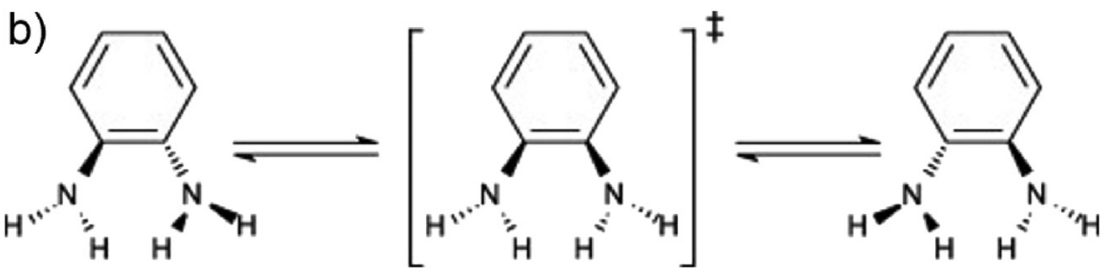

Fig. 3. (a) The $\mathbf{A B}$ intermediate bearing the $\mathrm{C}-\mathrm{OH}$ hemiaminal. (b) The excited form of $\mathbf{1}$ at the center: $\mathbf{1}^{*}$ (Reproduced from Ref. ${ }^{35}$ ).

$\mathbf{A B}$ intermediate. On the other hand, the probability for $\mathbf{1}^{*}$ to react with the cis conformer of $\mathbf{2} \mathbf{b}$ is much lower, since the cis conformation of this 1,2-dione is disfavored. ${ }^{9}$ Furthermore, the flexibility of $\mathbf{2} \mathbf{b}$ enables faster reaction towards $\mathbf{3} \mathbf{b}$ formation as shown by kinetic monitoring and ${ }^{13} \mathrm{C}$ CP-MAS NMR for the milling period records (Fig. 2b).

An interesting observation for both $\mathbf{3 a}$ and $\mathbf{3 b}$ mechanosynthesis is the reaction continuation in the powder when the grinding is interrupted. No further reaction occurs if dissolved. The reaction monitoring by ${ }^{13} \mathrm{C}$ CP-MAS NMR after a milling period for 3a (30 min) and 3b (15 min) synthesis (see Fig. S1 in Supplementary Data) showed progressive disappearance of $\mathbf{A B}$, previously formed and accumulated during the milling period for the case of $\mathbf{3 a}$, while for $\mathbf{3 b}$ no intermediate was detected.

In order to further investigate the thermodynamics of the reaction, calorimetric measurements were carried out isothermally at $25{ }^{\circ} \mathrm{C}$ with the reactant powder mixture in the post-milling period and showed different patterns of heat flow curves for each case (Fig. 4). In the case of 3a mechanosynthesis, the curves (Fig. 4a) have the highest heat flow at the beginning that decays rapidly, followed by a slower decrease. On the other hand, for $\mathbf{3 b}$, the heat flow decays constantly from the beginning during the first $12 \mathrm{~h}$ (Fig. 4b), indicating a different behavior for 3a. In this later case, considering the accumulation of $\mathbf{A B}$ under continuous mechanical stress, it induces the release of a large amount of heat resulting in that peak of heat flow. 

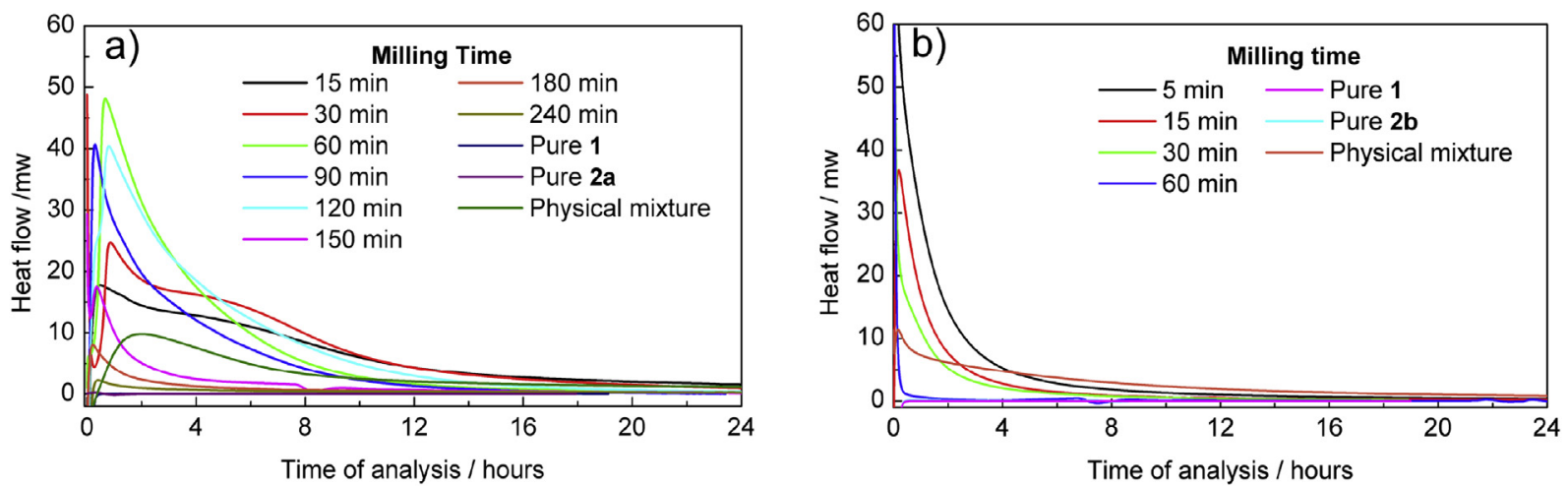

Fig. 4. Heat released by the reactant solid mixture for the following $24 \mathrm{~h}$ after milling: (a) 3a synthesis and (b) 3b synthesis.

Table 1

Heat released by the reactant solid mixture during the calorimetric measurements.

\begin{tabular}{|c|c|c|c|c|c|c|}
\hline \multicolumn{3}{|l|}{$3 a$} & \multicolumn{4}{|l|}{$3 b$} \\
\hline$t(\min )$ & Overall $\Delta H(\mathrm{~J})$ & $\Delta H^{\mathrm{a}}\left(\mathrm{kJ} \Delta \mathrm{mol}_{2 \mathrm{a}}^{-1}\right)$ & $t(\min )$ & Overall $\Delta H(\mathrm{~J})$ & $\Delta H^{\mathrm{b}}\left(\mathrm{kJ} \Delta \mathrm{mol}_{2 \mathrm{~b}}^{-1}\right)$ & $\Delta H^{\mathrm{c}}\left(\mathrm{kJ} \Delta \mathrm{mol}_{3 \mathrm{~b}}^{-1}\right)$ \\
\hline 15 & $-551.76 \pm 11.95$ & $-147.56 \pm 3.20$ & 5 & $-364.84 \pm 31.95$ & $-111.18 \pm 9.74$ & $-111.19 \pm 9.74$ \\
\hline 30 & $-616.02 \pm 11.32$ & $-155.97 \pm 2.86$ & 15 & $-238.39 \pm 26.64$ & $-86.52 \pm 9.67$ & $-106.49 \pm 11.90$ \\
\hline 60 & $-630.23 \pm 2.25$ & $-181.35 \pm 0.65$ & 30 & $-120.68 \pm 9.11$ & $-130.37 \pm 9.93$ & $-104.32 \pm 7.88$ \\
\hline $90^{\mathrm{d}}$ & -456.92 & -233.27 & $60^{\mathrm{d}}$ & -20.62 & - & - \\
\hline 120 & $-313.00 \pm 4.96$ & $-263.39 \pm 4.17$ & $\mathrm{PM}^{\mathrm{e}}$ & $-232.35 \pm 9.24$ & $-88.19 \pm 3.55$ & $-88.53 \pm 3.56$ \\
\hline $150^{\mathrm{d}}$ & -146.37 & -187.68 & & & & \\
\hline 180 & $-75.85 \pm 1.74$ & $-145.17 \pm 3.33$ & & & & \\
\hline $240^{\mathrm{d}}$ & -38.62 & -148.53 & & & & \\
\hline $\mathrm{PM}^{\mathrm{e}}$ & $-120.79 \pm 3.11$ & $-77.52 \pm 3.01$ & & & & \\
\hline
\end{tabular}

Heat released during analisis per mol of:

a 2 a consumed.

b $2 \mathbf{b}$ consumed.

c $\mathbf{3 b}$ formed.

d Single determination.

e $\mathrm{PM}=$ physical mixture.

Table 1 displays the integrations values of the curves (Fig. 4) for $24 \mathrm{~h}$ of monitoring. Such enthalpies incorporate contributions from all processes including reaction enthalpy and product crystallization. However, the heat of crystallization at $25^{\circ} \mathrm{C}$ can be neglected. For example, in the extreme case in which all the powder would undergo a crystallization towards the final crystalline product; the overall heat released would not exceed $2.5 \mathrm{~J}$ or $\mathbf{3 a}$ at this temperature. ${ }^{53}$ Furthermore, a critical amount of product should be present to start the nucleation and growth processes. In the case of $\mathbf{3 b}$, the estimated heat of crystallization at $25^{\circ} \mathrm{C}$ is about $53.7 \mathrm{~J}$; but the kinetics of transformation is also higher and thus, crystallization already occurs prior to analysis.
The values of heat released per mol of $2 \mathbf{a}$ consumed during the measurements are not constant for all milling times, confirming that the energy released does not come exclusively from the reaction between $\mathbf{1}$ and $\mathbf{2 a}$ to form $\mathbf{3 a}$. If so, the values should tend to that of physical mixture $\left(-77.52 \mathrm{~kJ} \Delta \mathrm{mol}_{2 \mathrm{a}}^{-1}\right.$, for a reaction extent of $25 \%$ ) that is mostly originated from the heat of reaction itself.

Thus, considering that, part of $\mathbf{1}$ and $\mathbf{2 a}$ is consumed during the milling period, although $\mathbf{3 a}$ is not formed yet, larger amount of $\mathbf{A B}$ is accumulated under mechanical action, thus releasing more heat towards $\mathbf{3 a}$ formation during the calorimetric runs when compared to overall reaction, from pure $\mathbf{1}+\mathbf{2 a}$ affording $\mathbf{3 a}$ (Scheme 2 ).

Unlike the values from Table 1 for $\mathbf{3 a}$, the values of heat released

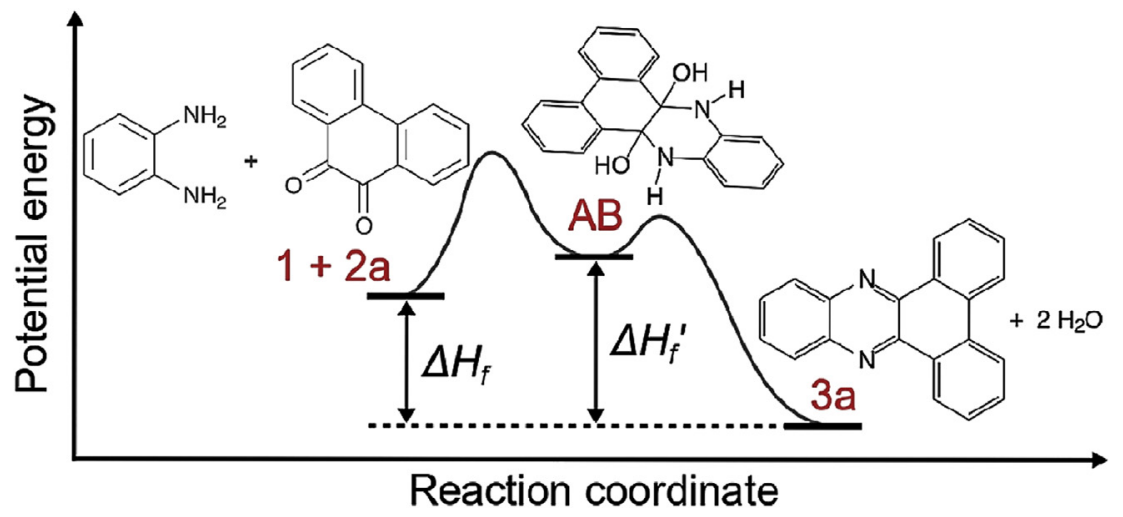

Scheme 2. The accumulated $\mathbf{A B}$ intermediate releases more heat than the overall reaction starting from $\mathbf{1}$ and $\mathbf{2 a}$. 
per mol of $\mathbf{2 b}$ consumed or $\mathbf{3 b}$ formed (Table 1) are statistically equivalent. Comparing these values at different milling times for $\mathbf{3 b}$ formation, with the value of heat released by the physical mixture (PM, Table 1) of $\mathbf{1}$ and $\mathbf{2 b}$ they can be predominantly due to the heat of reaction despite the exothermic effect of crystallization. The heat released related to reaction extent indicates clearly that there was in this case no accumulation of activated species of higher level of energy during the milling process.

The results of calorimetry are also valuable in understanding mechanistic mechanochemistry. First, pure milled reagents 1, 2a and $\mathbf{2 b}$ did not show any thermic event, indicating that the heat released from the runs with a mixture of reactants is not a consequence of temperature increase during milling. Second, the high heat released, even for shorter milling times such as $5-15 \mathrm{~min}$, indicates that co-milling of the raw materials is more efficient to induce reaction than the physical mixture of very fine reactant powders (milled during $30 \mathrm{~min}$ prior to mixing), thus demonstrating the critical role of mechanical energy in addition to particle breakage, mixing and surface renewal. It must be noted that the heat released by the physical mixtures is associated to the huge defective surface area generated by the pre-milling, increasing the free energy and facilitating reactions on the interfaces. ${ }^{14 c, 54}$ HPLC detected only traces of reaction from the mixture of the non-milled reactants.

\section{Conclusion}

In summary, this study allowed in-depth knowledge of $\mathbf{3 a}$ synthesis through the experimental evidence of a hemiaminal intermediate formed under mechanochemical conditions and highlighted by ${ }^{13} \mathrm{C} C P-M A S ~ N M R$, leading to the exothermic formation of 3a. The primary contribution of calorimetry, first used here for this purpose, equally emphasized the high energetic level obtained under milling. The comparison with $\mathbf{3 b}$ synthesis was important to demonstrate that this intermediate can be generated and accumulated upon solvent-free application of mechanical stress. The mechanical action showed to be able to induce transformations other than ones in solution directly from excited states, unstable in solvated media, but that reacts with $\mathbf{2 a}$ by a concerted mechanism. The results also value the mechanochemistry as a means to overcome solvated media limitations by enabling generation and trapping of reactive intermediates. Owing the susceptibility of evidencing very original mechanisms that appear within divided solids undergoing mechanical stresses, experimental and computational investigations, linking the consequences of mechanical energy from powders and down to the atomic scale, are essential for further progress in the field of mechanochemistry and the future formalization of its rules.

\section{Experimental}

\subsection{General procedure for $\mathbf{3 a}$ and $\mathbf{3} \boldsymbol{b}$ condensed 1,4-diazines synthesis}

For a typical experiment, $2 \mathrm{~g}$ of powder composed of stoichiometric amounts of 1,2-diamine and 1,2-dione, without previous mechanical treatment, were placed in the bowl of a vibratory ballmill (Pulverisette 0, Fritsch) with a single ball at the equilibrium temperature for milling $\left(25^{\circ} \mathrm{C}\right)$. The amplitude was adjusted at $2 \mathrm{~mm}$ (for further details concerning the milling device, see ref. ${ }^{28}$ ). Equimolar amounts of $o$-phenylenediamine (1, $0.6698 \mathrm{~g})$ and 9,10phenanthrenequinone (2a, $1.3204 \mathrm{~g}$ ) were used for dibenzo[a,c] phenazine (3a) synthesis, and $\mathbf{1}(0.6793 \mathrm{~g})$ and benzil (2b, $1.3207 \mathrm{~g})$ for 2,3-diphenylquinoxaline (3b) synthesis. The grinding system, bowl + ball, was to equilibrate at the required temperature $\left(25^{\circ} \mathrm{C}\right)$ for at least $12 \mathrm{~h}$ prior to each run. The total weight of the powder of $2 \mathrm{~g}$ was used for all experiments.

\subsection{Dibenzo[a,c]phenazine (3a)}

mp: $224-226{ }^{\circ} \mathrm{C}^{1} \mathrm{H}$ NMR $\left(300 \mathrm{MHz}, \mathrm{CDCl}_{3}\right) \delta \mathrm{ppm}: 7.68-7.83$ $(\mathrm{m}, 4 \mathrm{H}), 7.87(\mathrm{dd}, 2 \mathrm{H}, J=6.6,3.4 \mathrm{~Hz}), 8.36(\mathrm{dd}, 2 \mathrm{H}, J=6.5,3.4 \mathrm{~Hz})$, $8.54(\mathrm{dd}, 2 \mathrm{H}, J=7.7,1.7 \mathrm{~Hz}), 9.41(\mathrm{dd}, 2 \mathrm{H}, J=7.9,1.7 \mathrm{~Hz}) .{ }^{13} \mathrm{C} \mathrm{NMR}$ (75 MHz, $\mathrm{CDCl}_{3}$ ) $\delta$ ppm: 122.89 (s, 2C), 126.32 (s, 2C), 127.94 (s, 2C), 129.30 (s, 2C), 129.86 (s, 2C), 129.99 (s, 2C), 130.39 (s, 2C), 132.03 (s, 2C), $141.94(\mathrm{~s}, 2 \mathrm{C}, \mathrm{C}=\mathrm{N}$ ), 142.27 (s, 2C). HRMS (ESI, TOF) $\mathrm{m} / \mathrm{z}$ : $\mathrm{C}_{20} \mathrm{H}_{13} \mathrm{~N}_{2}$ (calc./found) 281.1079/281.1081 [M+H $\left.\mathrm{H}^{+}\right]$.

\subsection{2,3-Diphenylquinoxaline (3b)}

mp: $125-127{ }^{\circ} \mathrm{C} .{ }^{1} \mathrm{H}$ NMR $\left(300 \mathrm{MHz}, \mathrm{CDCl}_{3}\right) \delta$ ppm: 7.30-7.46 (m, 6H), 7.47-7.62 (m, 4H), $7.80(\mathrm{dd}, 2 \mathrm{H}, J=6.4,3.4 \mathrm{~Hz}), 8.21$ (dd, $2 \mathrm{H}, J=6.4,3.4 \mathrm{~Hz}) .{ }^{13} \mathrm{C} N M R\left(75 \mathrm{MHz}, \mathrm{CCl}_{3}-d\right) \delta \mathrm{ppm}: 128.27(\mathrm{~s}, 4 \mathrm{C})$, 128.81(s, 2C), 129.20 (s, 4C), 129.85 (s, 2C), 129.97 (s, 2C), 139.07 (s, 2C), $141.22(\mathrm{~s}, 2 \mathrm{C}), 153.47(\mathrm{~s}, 2 \mathrm{C}, \mathrm{C}=\mathrm{N}$ ). HRMS (ESI, TOF) $\mathrm{m} / z$ : $\mathrm{C}_{20} \mathrm{H}_{15} \mathrm{~N}_{2}$ (calc./found) $283.1235 / 283.1237\left[\mathrm{M}+\mathrm{H}^{+}\right]$.

\section{Acknowledgments}

The authors acknowledge CNRS/JSPS France-Japan joint research project ( ${ }^{\circ}$ PRC0709, 2013-2014) and the French Embassy in Japan (Exploration 2017) for financial support, Séverine Patry for help in calorimetry and Yannick Coppel for NMR experiments.

\section{Appendix A. Supplementary data}

Supplementary data related to this article can be found at http:// dx.doi.org/10.1016/j.tet.2017.03.014.

\section{References}

1. Achelle S, Baudequin C, Plé N. Dye Pigment. 2013;98:575-600.

2. Kaim W. Angew Chem Int Ed. 1983;22:171-190.

3. Pereira JA, Pessoa AM, Cordeiro MNDS, et al. Eur J Med Chem. 2015;97: $664-672$.

4. Dolezal M, Zitko J. Expert Opin Ther Pat. 2015;25:33-47.

5. González M, Cerecetto H. Expert Opin Ther Pat. 2012;22:1289-1302.

6. Laursen JB, Nielsen J. Chem Rev. 2004:104:1663-1686.

7. Kaupp G, Naimi-Jamal MR. Eur J Org Chem. 2002;2002:1368-1373.

8. (a) Carlier L, Baron M, Chamayou A, Couarraze G. Tetrahedron Lett. 2011;52: 4686-4689;

(b) Carlier L, Baron M, Chamayou A, Couarraze G. Powder Technol. 2013;240: $41-47$.

9. Oliveira PFM, Baron M, Chamayou A, et al. ChemistrySelect. 2016;1:984-988.

10. (a) James SL, Adams CJ, Bolm C, et al. Chem Soc Rev. 2012;41:413-447; (b). In: Ranu B, Stolle A, eds. Ball Milling towards Green Synthesis: Applications, Projects, Challenges. Cambridge: Royal Society of Chemistry; 2014;

(c) Wang G-W. Chem Soc Rev. 2013;42:7668-7700;

(d) Hernández JG, Friščić T. Tetrahedron Lett. 2015;56:4253-4265;

(e) Declerck V, Nun P, Martinez J, Lamaty F. Angew Chem Int Ed. 2009;48: 9318-9321.

11. Braga D, Maini L, Grepioni F. Chem Soc Rev. 2013;42:7638.

12. Friščić T. Metal-organic frameworks: mechanochemical synthesis strategies. In: Encycl. Inorg. Bioinorg. Chem. Chichester, UK: John Wiley \& Sons, Ltd; 2014: $1-19$.

13. (a) Boldyrev VV. Russ Chem Rev. 2006;75:177-189; (b) Boldyreva E. Chem Soc Rev. 2013:42:7719-7738.

14. (a) Descamps M, Willart JF. Adv Drug Deliv Rev. 2016;100:51-66; (b) Willart JF, Descamps M. Mol Pharm. 2008;5:905-920; (c) Descamps M, Willart JF, Dudognon E, Caron V. J Pharm Sci. 2007;96: 1398-1407.

15. Kaupp G. CrystEngComm. 2006;8:794-804.

16. Oliveira PFM, Baron M, Chamayou A, André-Barrès C, Guidetti B, Baltas M. RSC Adv. 2014;4:56736-56742.

17. Rodríguez B, Bruckmann A, Bolm C. Chem - A Eur J. 2007;13:4710-4722.

18. Cravotto G, Garella D, Carnaroglio D, Gaudino EC, Rosati O. Chem Commun. 2012;48:11632.

19. (a) Hickenboth CR, Moore JS, White SR, Sottos NR, Baudry J, Wilson SR. Nature. 2007;446:423-427; 
(b) Wollenhaupt M, Krupička M, Marx D. ChemPhysChem. 2015;16:1593-1597; (c) Li J, Nagamani C, Moore JS. Acc Chem Res. 2015;48:2181-2190;

(d) Friedrichs J, LüßMann M, Frank I. ChemPhysChem. 2010;11:3339-3342.

20. Zefirov NS, Sereda GA, Volkov VP, Tkachenko SE, Zyk NV. Chem Heterocycl Compd. 1996;32:577-579.

21. (a) Michalchuk AAL, Tumanov IA, Drebushchak VA, Boldyreva EV. Faraday Discuss. 2014;170:311-335.

(b) Michalchuk AAL, Tumanov IA, Boldyreva EV. CrystEngComm. 2013;15: 6403-6412.

22. Tan D, Mottillo C, Katsenis AD, Štrukil V, Friščić T. Angew Chem - Int Ed. 2014;53:9321-9324

23. Friščić T, Fábián L. CrystEngComm. 2009;11:743-745.

24. Štrukil V, Gracin D, Magdysyuk OV, Dinnebier RE, Friščić T. Angew Chem Int Ed. 2015;54:8440-8443.

25. Kuroda R, Higashiguchi K, Hasebe S, Imai Y. CrystEngComm. 2004;6:463.

26. Kaupp G, Naimi-Jamal MR. CrystEngComm. 2005;7:402.

27. Kaupp G. CrystEngComm. 2003;5:117.

28. Rothenberg G, Downie AP, Raston CL, Scott JL. J Am Chem Soc. 2001;123: 8701-8708.

29. Chadwick K, Davey R, Cross W. CrystEngComm. 2007;9:732.

30. (a) Luty T, Ordon P, Eckhardt CJ. J Chem Phys. 2002;117:1775;

(b) Luty T, Eckhardt CJ. J Am Chem Soc. 1995;117:2441-2452.

31. Gilman JJ. Science. 1996;274:65 (80- ).

32. (a) Senna M. J Mater Sci. 2004;39:4995-5001;

(b) Pradipta M, Watanabe H, Senna M. Solid State Ionics. 2004;172:169-172.

33. Kuklja MM, Stefanovich EV, Kunz A. B J Chem Phys. 2000;112:3417.

34. Gavezzotti A, Simonetta M. Chem Rev. 1982;82:1-13.

35. Haruta N, Sato T, Tanaka K, Baron M. Tetrahedron Lett. 2013;54:5920-5923.

36. Muddasir H, Lu P, Gu C, et al. Chem Res Chin Univ. 2009;25(6):950-956.

37. Trotzki R, Hoffmann MM, Ondruschka B. Green Chem. 2008;10:767.
38. Trotzki R, Hoffmann MM, Ondruschka B. Green Chem. 2008;10:873-878.

39. Middleton DA, Le Duff CS, Berst F, Reid DG. J Pharm Sci. 1997:86:1400-1402.

40. Middleton DA, Patching SG. Solid-state NMR spectroscopy in drug design and discovery. In: Stereoselective Synth. Drugs Nat. Prod. Hoboken, NJ, USA: John Wiley \& Sons, Inc; 2013:1-20.

41. Matsuzaki SY, Gotoh M, Kuboyama A. Mol Cryst Liq Cryst. 1987;142:127-139.

42. Rae AD, Willis AC. Z Fur Krist. 2003;218:221-230.

43. Brown CJ, Sadanaga R. Acta Crystallogr. 1965;18:158-164.

44. More M, Odou G, Lefebvre J. Acta Crystallogr Sect B Struct Sci. 1987;43:398-405.

45. Chippendale AM, Mathias A, Aujla RS, Harris RK, Packer KJ, Say BJ. J Chem Soc Perkin Trans. 1983;2:1357.

46. Rezler M, Zołek T, Wolska I, Maciejewska D. Acta Crystallogr Sect B Struct Sci Cryst Eng Mater. 2014;70:820-827.

47. Cherkasov VK, Druzhkov NO, Kocherova TN, Shavyrin AS, Fukin GK. Tetrahedron. 2012;68:1422-1426.

48. Anitha P, Manikandan R, Viswanathamurthi P. J Coord Chem. 2015;68: $3537-3550$.

49. Afrasiabi Z, Sinn E, Lin W, Ma Y, Campana C, Padhye S. J Inorg Biochem. 2005;99: $1526-1531$.

50. Anitha P, Manikandan R, Endo A, Hashimoto T, Viswanathamurthi P. Spectrochim Acta - Part A Mol Biomol Spectrosc. 2012;99:174-180.

51. Czapik A. Gdaniec M. Acta Crystallogr Sect C Cryst Struct Commun. 2010;66: o198-201.

52. Delogu F. Mater Chem Phys. 2012;137:297-302.

53. This value is the heat of crystallization at $25^{\circ} \mathrm{C}$. I was estimated from the the heat of fusion/heat of crystallization at melting temperature. Based on: Willart J-F, Carpentier L, Danède F, Descamps M. J Pharm Sci. 2012;101:1570-1577.

54. (a) Navrotsky A, Mazeina L, Majzlan J. Science. 2008;319:1635-1638 (80- ); (b) Fecht HJ. Nature. 1992;356:133-135. 